\title{
State of the art of pricing policy in air transportation: network carriers vs. low-cost airlines
}

Estado da arte da política de preços no transporte aéreo: companhias aéreas de linha vs. companhias aéreas de baixo custo

\author{
Christian Wehner \\ University of Seville, Faculty of Finance and Tourism, Seville, Spain, christian.wehner@yahoo.de \\ Jesús Manuel López-Bonilla \\ University of Seville, Faculty of Economic and Management Sciences, Seville, Spain, lopezbon@us.es \\ Luis Miguel López-Bonilla \\ University of Seville, Faculty of Economic and Management Sciences, Seville, Spain, luismi@us.es \\ José António C. Santos \\ University of Algarve, ESGHT and CIEO/CINTOURS Research Centre, Faro, Portugal, jasantos@ualg.pt
}

\begin{abstract}
The modern air transport industry is highly competitive. To survive in the market, the implementation of a successful marketing strategy is fundamental. In particular, an effective pricing policy has become crucial for airlines to remain profitable. Correspondingly, the different types of airline in the market have also established very distinct pricing policies. The present study is based on a literature review and presents the state of the art of pricing policy in air transportation. The aim is to compare and discuss the pricing strategies of network carriers and lowcost airlines. Special attention is paid to Revenue Management, which is a very important management tool used by airlines to take advantage of the differences in willingness to pay of passengers. The pricing policy, however, depends on the overall business strategy of the airline. Results show many differences, resulting from the fact that these two types of airline are characterized by very different fundamental business models and, correspondingly, also target groups. Since network carriers and also low-cost airlines have adjusted their pricing strategies lately, these recent developments will be discussed as well. This paper adds to the knowledge of this topic because it presents the most up-to-date and complete study on pricing regarding network carriers vs. low-cost airlines.
\end{abstract}

Keywords: Pricing policy, Revenue Management, willingness to pay, network carriers, low-cost airlines.

\section{Resumo}

A moderna indústria do transporte aéreo é altamente competitiva. Para sobreviver no mercado, a implementação de uma estratégia de marketing bem-sucedida é fundamental. Em particular, uma política de preços eficaz tornou-se crucial para as companhias aéreas continuarem lucrativas. Os diferentes tipos de companhias aéreas no mercado também estabeleceram políticas de preços muito distintas. 0 presente estudo baseia-se numa revisão da literatura e apresenta o estado da arte da política de preços no transporte aéreo. $O$ objetivo é comparar e discutir as estratégias de preços de companhias aéreas de linha e companhias aéreas de baixo custo. Atenção especial é dada à Gestão de Receitas (Revenue Management), que é uma ferramenta de gestão usada pelas companhias aéreas para aproveitar as diferenças na disposição de pagar dos passageiros. A política de preços, no entanto, depende da estratégia geral de negócios da companhia aérea. Os resultados mostram muitas diferenças, resultantes do facto de que esses dois tipos de companhias aéreas são caracterizados por modelos de negócios fundamentais muito diferentes e, correspondentemente, também grupos-alvo. Como as operadoras de rede e também as companhias aéreas de baixo custo ajustaram as suas estratégias de preços ultimamente, esses desenvolvimentos recentes também serão discutidos. Este documento contribui para o conhecimento deste tópico, pois apresenta o estudo mais atualizado e completo sobre preços de companhias aéreas de linha versus companhias aéreas de baixo custo.

Palavras-chave: Política de preços, Revenue Management, disposição de pagar, operadoras de rede, companhias aéreas de baixo custo.

\section{Introduction}

The continuous entry of new airlines over the last decades has turned the air transportation sector into a highly competitive environment (Oliveira, 2008). Therefore, the implementation of a successful business model which best meets customer needs became crucial for airlines (Wehner, López-Bonilla \& LópezBonilla, 2017). According to Porter (1985), two fundamental strategies can be distinguished. On the one hand, a differentiation strategy, which means offering a service at a superior quality level. The other strategic option is cost leadership, which is based on strict cost savings over the whole of the value chain to be able to provide customers a service at a very low price. Both generic strategies can be found in the air transport sector in the form of different types of airline. Whereas traditional airlines, also called network carriers, normally follow a differentiation strategy (Schulz, 2009), low- cost airlines typically are established in the market with a strict strategy of cost leadership (Cento, 2009).

In accordance with their overall business model, both airline types implement a series of strategic measures (Table 1). To be able to provide a large number of different flight connections and destinations to their customers, network carriers offer many connecting flights using big airports as hubs. To increase the route network even more, network carriers also cooperate with each other in the form of codeshare agreements and alliances. Since this type of airline operates worldwide, the fleet is very heterogeneous and consists of many different short-haul as well as long-haul aircraft. In contrast, low-cost airlines only offer direct flights and do not collaborate with other airlines, which reduces their complexity. Another characteristic of lowcost airlines is the fact that mainly smaller and cheaper airports are served, in order to save costs. Furthermore, no long-haul flights are offered, which also means that the fleet is very 
homogenous, consisting only of smaller planes and not uncommonly only of one certain type of aircraft.

Table 1 - Characteristics of network carriers and low-cost airlines

\begin{tabular}{|l|c|c|}
\hline & Network carriers & Low-cost airlines \\
\hline Generic strategy & differentiation & cost leadership \\
\hline Flight plan & $\begin{array}{c}\text { many connecting } \\
\text { flights }\end{array}$ & only direct flights \\
\hline Collaboration & yes & no \\
\hline Airports served & big hubs, medium- & primarily small \\
\hline Geographical & sized \\
coverage & worldwide & continental \\
\hline Fleet & heterogeneous & homogeneous \\
\hline
\end{tabular}

Not only do the general strategy of network carriers and lowcost airlines differ, but also their target groups, as Baker (2013) points out. Network carriers are characterized by a full market coverage, i.e., their target groups include leisure as well as business travellers. However, since these customer groups show many differences in their consumer behaviour, particularly with regard to price and time sensitivity (Doganis, 2010), a differentiated service in the form of different travel classes is provided to each segment (Clark, 2007). To meet the customer needs of time sensitive business travellers, a spacious travel class which allows working during the flight is offered, along with additional services before and after the flight to save time, e.g., separate check-in counters and priority baggage delivery (Pompl, 2007). The less expensive but also less comfortable economy class of traditional airlines aims at holidaymakers, who typically show a higher price sensitivity than business travellers and therefore accept a certain degree of inconvenience in order to benefit from lower airfares (Gilbert \& Wong, 2003; Mensen, 2013).

In contrast, the target group of low-cost airlines is very homogeneous and consists of highly price sensitive leisure travellers, who seek air transportation from one place to another at the lowest airfares, as Domanico (2007) explains. O'Connell and Williams (2005) revealed that especially younger passengers less than 24 years old are attracted by low-cost airlines. Due to the homogeneity of the target group, the offerings are also limited, to only one very modest travel class (Cento, 2009).

Based on the overall business model and the characteristics of the target groups, each type of airline implements a suitable pricing policy. One aspect with particular relevance is Revenue Management, which is a special form of price discrimination based on the differences in willingness to pay of customers. It strives for maximizing the capacity utilization (Friesen \& Reinecke, 2007). The importance of Revenue Management in the airline business results from a typical characteristic of its services, which is that they cannot be stored for later consumption (Edgett \& Parkinson, 1993). In other words, every seat on a certain flight which is not sold involves lost revenues for the airline. Since the operating costs of an aircraft are very high (Mensen, 2013), but the incremental costs of an additional passenger are very low, one of the main objectives of every airline company is to achieve a high degree of capacity utilization (Dettmer, Hausmann \& Schulz, 2008; Heidig \& Tomczak, 2014).

The principal purpose of the present study is to discuss the pricing policies of network carriers and low-cost airlines. At first, the general pricing strategies of the two airline types will be compared. In the following, the important but also very complex Revenue Management of airlines will be analysed in detail. Before discussing the established Revenue Management of the two airline types, the general idea and mechanism of Revenue Management in air transportation will be presented. Since many strategy adaptations can be noticed lately among network carriers as well as low-cost airlines, the subsequent chapter focusses on these recent developments with regard to pricing. At the end, some conclusions are drawn.

\section{Airline types and pricing}

As mentioned earlier, network carriers and low-cost airlines are established with opposing business models in the market which, consequently, also leads to very different pricing policies. Since network carriers offer a high-quality service, the general price level of their flights is also fairly high. In contrast, low-cost airlines sacrifice service quality to a certain extent and offer the basic service of air transportation at a very low price. A study conducted by Lawton (2002) found that, on average, the ticket prices of low-cost airlines are $40 \%-60 \%$ lower than comparable flights of network carriers. However, beside this fundamental characteristic, many other differences in the pricing strategies between these two airline types can be observed:

- One important difference between network carriers and low-cost airlines exists with regard to their tariff systems. Network carriers implement distinctive tariff conditions for each travel class, which are in accordance with the needs of the respective customer group. Therefore, the fare conditions of business class tickets usually include the right to change flights at little or no charge, which is an important aspect for business travellers since changes in plan on short notice are very frequent on business trips. In contrast, economy class tickets are characterized by very strict fare conditions and no changes are allowed (Pompl, 2007). Yet, since vacations are normally planned well in advance of the trip and changes or cancelations are uncommon, leisure travellers are willing to give up this flexibility in return for lower ticket prices (Gursoy \& Gavcar, 2003). Furthermore, network carriers implement certain conditions for their discounted round trip fares in order to exclude the priceinsensitive business travellers from these cheaper flight 
tickets. Very common is the restriction of spending at least one Saturday at the destination, since business people usually travel on weekdays and return at the latest by Friday (Schulz, 2009; Tretheway, 2004). In comparison, the tariff system of low-cost carriers is very simple. Due to the fact that these airlines only offer one travel class, the tariff system is reduced to only one tariff, which includes very strict conditions (Cento, 2009). Besides, the flights are offered individually, meaning that no special tariffs for return flights apply (Tretheway, 2004).

- Furthermore, the airline types differ substantially in the manner of offering the supplemental services and products of a flight. The pricing of traditional airlines is based on "bundling", which means that additional components are offered together with the air transportation (Gillen \& Morrison, 2003). By doing so, a reasonably high-quality package of services and products is offered, which saves the customer the time to combine it on their own, as explained by Böhler and Scigliano (2005). On the other hand, low-cost airlines offer the additional services separately, which gives customers the flexibility to choose and combine the ones corresponding to their personal preferences, also called "a la carte" pricing (O'Connell, 2011; Shaw, 2011). However, the number of additional services provided is limited to the basic ones. Nevertheless, the vending of these additional services, e.g., checked luggage or meals and beverages during the flight, is of great relevance for low-cost airlines. For some airlines it is already responsible for more than one-quarter of total revenue and is steadily increasing, as Sorensen (2018) emphasizes.

- Another major difference can be found regarding geographical pricing, which results from the distinct overall business strategies of network carriers and low-cost airlines. Network carriers typically operate at a global level and, consequently, in countries which show many differences with respect to economic situation, distribution of wealth, available income of the households, as well as currency (Narangajavana, Garrigos-Simon, Garcia \& ForgasColl, 2014; Perlitz, 2004). All these aspects have to be considered in the determination of the prices of the flight tickets. To limit the available airfares to a specific country, network carriers implement certain conditions. Typically, in connecting flights the omission of a flight segment results in the expiration of the right to fly the following flight segments. With this restriction, airlines prevent customers from buying cheap connecting flights starting in another country and boarding in the transit airport, as Conrady, Fichert and Sterzenbach (2013) explain. Low-cost airlines normally abstain from geographical pricing. Many times, restrictive regulations exist in the operating region of these airlines, which hinder an international price discrimination. For example, airlines operating in the European Union are obliged to give all EU citizens access to the same prices, regardless of their nationality or country of residence

\section{(EUROPA, 2018)}

- As De Boer and Gudmundsson (2012) remark, a very wellestablished pricing instrument with a long history in air transportation are customer loyalty programmes. However, this is only among network carriers. The main idea of these frequent flyer programmes is to retain customers by offering the possibility to collect miles, which can be used to buy flights or profit from other benefits such as travel class upgrades or VIP lounge access (De Boer \& Gudmundsson, 2012; Wagner, 2005). Many studies confirm that the participation in a frequent flyer programme can highly influence the purchasing decision of a customer (Chin, 2002; Dolnicar, Grabler, Grün \& Kulnig, 2011; Hess, Adler \& Polak, 2007; Nako, 1992). Furthermore, the data collected from these programmes are a cheap source of information about clients, which helps to optimize marketing activities (Wagner, 2005). Despite these advantages, low-cost airlines, on the other hand, do not offer any kind of loyalty programme, mainly to save costs, as Ruperti (2012) points out.

\section{Revenue Management}

Although being a wide-spread and important management tool for many years, until now there has been no clear definition of Revenue Management, and many approaches to its explanation can be found (e.g., Cross, 1995; Donaghy, McMahon-Beattie \& McDowell, 1997; Klein, 2001). However, there is a consensus that the main goal of Revenue Management is the maximization of profits, achieved by influencing sales with price-based measures (Klein \& Steinhardt, 2008). The principal idea is a simultaneous and dynamic management of price and capacity. It can be described as a special form of price discrimination based on the differences in willingness to pay of customer groups (Heidig \& Tomczak, 2014). As Vasigh, Fleming and Tacker (2013) point out, the main difference between classic forms of price discrimination and Revenue Management is that whereas the former are characterized as being static tools, the latter one are considered the dynamic management of prices over time.

Stuhlmann (2000) remarks that there is a heterogeneity on the literature not only related to the definition, but also regarding the terminology. It can be observed that especially the term "Yield Management" is often found as a synonym for Revenue Management (e.g., Malaval, Bénaroya \& Aflalo, 2014; Pfeifer, 1989; Weatherford, 1997). Yet, in practice and particularly in the air transportation context, the term "Revenue Management" is well established nowadays, as Klein and Steinhardt (2008) confirm.

Revenue Management is an instrument used in many services industries, e.g. hotels or car rentals (Heidig \& Tomczak, 2014; Phillips, 2005). However, especially in the airline business, Revenue Management plays an extraordinary role, in which it also originated. The first Revenue Management system was implemented by American Airlines in the mid-eighties as a result of the intense competition it was facing by the entry of 
low-cost airlines (Cross, 1997). Nowadays, all major airlines around the globe have established a Revenue Management system for all their offered flights, as the study of Weatherford (2009) reveals. On average, the use of a Revenue Management system allows airlines to increase their profits by around $5 \%$ (Çetiner, 2013; Luo \& Peng, 2007).

In air transportation, Revenue Management is related to time, more specifically, to the travel date as well as the purchase date. The intention is to profit from the differences in willingness to pay with regard to these aspects. Firstly, airlines make use of the higher price acceptance of customers when travelling in peak seasons compared to periods with a lower demand for travel. Secondly, airlines aim at taking advantage of the higher willingness to pay for flights for which the intended flight date is closer to the purchase date (Friesen \& Reinecke, 2007). During the whole selling period of the flight tickets, which is usually a maximum of one year, airlines continuously optimize the prices and the capacity utilization, always taking into consideration these mentioned differences in willingness to pay of the customers (Michel \& Zellweger, 2014).

The challenge for airlines is to estimate accurately the demand and the sales of flight tickets in order to avoid lost profits, as Heidig and Tomczak (2014) point out. Vasigh et al. (2013) explain that, in a simple case, this means that if there is only one free seat left on a flight, an airline has to decide whether to sell it now at a low price or wait for a passenger with a higher willingness to pay close to the flight date. Therefore, the precise prediction of demand is a fundamental aspect of successful Revenue Management, as Vasigh et al. (2013) conclude.

An important aspect of Revenue Management in air transportation is overbooking, meaning that an airline sells more flight tickets than available seats on the aircraft (Amaruchkul \& Sae-Lim, 2011). The reason is that there is typically a certain percentage of passengers which does not appear for a flight without prior announcement, so-called "noshows" (Walczak, Boyd \& Cramer, 2012). This is especially the case on flights with a high proportion of business travellers, who usually choose tariffs which permit the change or annulation of the flight, even after flight departure, as Conrady et al. (2013) explain. However, the risk of overbooking is that there are not enough seats for all passengers on a flight and some travellers have to be rebooked on a later flight (Wirtz \& Heidig, 2014). This not only results in high costs for airlines (e.g. in the form of compensation and paying the expenses of accommodation), but also in high dissatisfaction of the concerned travellers (Lindenmeier \& Tscheulin, 2008; Wirtz \& Heidig, 2014). Consequently, an accurate prediction of the number of no-shows is crucial for airlines to reduce the cases of denied boardings to a minimum.

From a customer perspective, Revenue Management by airlines means that flights in the off-season, which are furthermore bought a long time in advance, usually are very cheap. In contrast, flight tickets purchased very shortly before departure, especially in a peak season, are very expensive. As Wirtz and Heidig (2014) stress, this could lead to a perceived unfairness among customers and therefore an adequate communication of the price differences is of major importance for airlines to increase the perceived justice and customer satisfaction.

As was discussed earlier, network carriers and low-cost airlines are established with very different pricing strategies in the market. This also applies to their implemented Revenue Management. As Talluri and Van Ryzin (2004) point out, whereas the central element of the Revenue Management of network carriers is the management of capacity, for low-cost airlines the price is the fundamental aspect. In the following, the Revenue Management of both types of airline will be analysed in detail.

\section{a) Revenue Management of network carriers}

The fundamental procedure of Revenue Management of traditional airlines is to estimate the demand and the different prices the customers are willing to pay in individual time intervals during the sales period. Based on these estimates, certain contingents of different ticket prices are determined for the time interval. This is done during the whole sales period, always taking into account the remaining free capacity in the plane (Conrady et al., 2013; Friesen \& Reinecke, 2007).

In Figure 1, an example of Revenue Management for the economy class is illustrated. As can be seen, at the beginning there are many tickets offered at the cheapest price. In contrast, at the end in the last time interval, the contingents of the higher airfares are much larger, which is in accordance with the higher willingness to pay of customers close to the flight date. In each time interval, when the contingent of cheaper airfares is sold out, the higher ticket prices are offered to the customer. Nonetheless, since in a later time interval also cheaper price levels are available again, it is possible that a customer purchases a flight at a lower price than a passenger who bought his flight at an earlier time. However, this becomes less likely over time, since the contingent of cheap airfares permanently decreases.

Figure 1 - Revenue management of network carriers

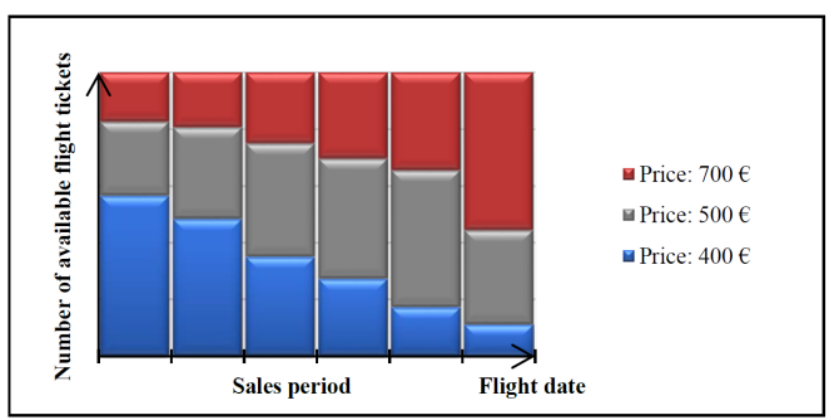

Source: adapted from Conrady et al. (2013).

Overbooking is a very important practice for network carriers, especially on routes with a high share of business travellers and, consequently, also a high number of no-shows. However, the risks of overbookings are limited. If a travel class is overbooked, 
many times there is the possibility of upgrading a passenger to a superior travel class. Yet, even in the case when the flight is completely full and some customers have to change to a later flight, the inconveniences often are minor because network carriers typically provide high flight frequencies, as Lindenmeier and Tscheulin (2008) remark. Another circumstance which is of relevance is the fact that network carriers usually possess a large fleet consisting of different aircraft and therefore the capacity is not necessarily limited. In the case that the demand for a flight is very high, airlines could switch to a bigger plane, if available (Frank, Friedemann, Mederer \& Schroeder, 2006). However, it has to be taken into consideration that the operating costs differ substantially between aircraft of different sizes. Therefore, changing to a bigger plane, from an economic point of view, is only reasonable if the number of overbookings is considerably high (Çetiner, 2013; Wang \& Meng, 2008).

The Revenue Management of network carriers is highly complex, especially considering the fact that it has to be done for each travel class separately (Conrady et al., 2013). Furthermore, the many connecting flights which are offered by these airlines increase the complexity. As Walczak et al. (2012) explain, airlines have to decide whether to sell a seat on a flight now or save it for a possible passenger who seeks a connecting flight at a later time. Besides, another aspect which complicates Revenue Management is the membership in an alliance, as Graf and Kimms (2013) point out. On the one hand, this gives the airline the possibility to increase its own capacity by offering flights from other members. However, on the other hand, other airlines of the alliance also have this option.

\section{b) Revenue Management of low-cost airlines}

Compared to network carriers, the Revenue Management of low-cost airlines is much less complex, as Friesen and Reinecke (2007) point out. This results from several basic strategic characteristics of their business model. Firstly, low-cost airlines only offer one travel class, which means that also the Revenue Management is limited to only this travel class. Secondly, no connecting flights are provided, implying that no decisions have to be made whether or not to hold back the sale of certain flights. Thirdly, low-cost airlines don't participate in alliances or make other kinds of agreements with other airlines, which reduces the complexity. Cento (2009) explains that, in general, their Revenue Management consists in a price change over time for a flight, depending on the development of the demand for the flight. Another fundamental aspect is that, due to the increasing willingness to pay of customers as the flight date approaches, ticket prices increase accordingly. This also confirms the study of Malighetti, Paleari and Redondi (2009), in which it was observed that during the sales period the airfares of low-cost airlines increased progressively. Especially a few days before the flight date, a rapid price increase can be seen. The typical development of the airfares of low-cost carriers over time is illustrated in Figure 2.

Figure 2 - Development of airfares of low-cost airlines over time

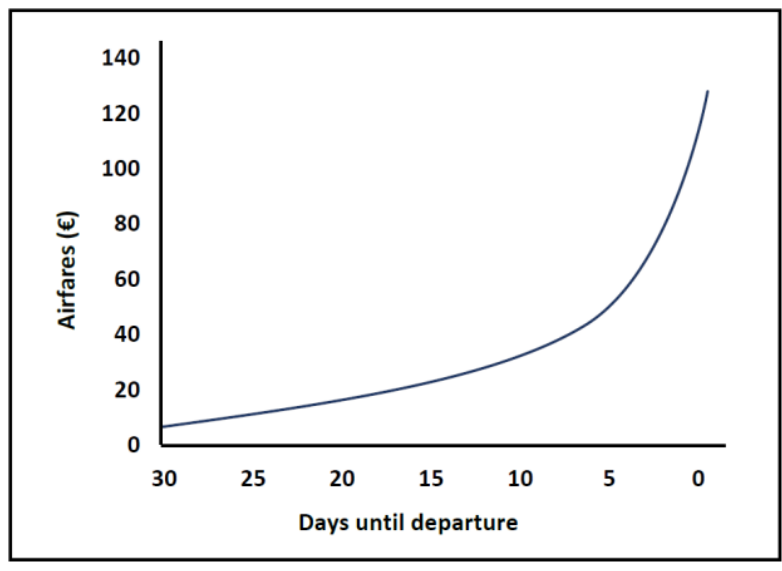

Source: adapted from Malighetti et al. (2009).

Cento (2009) points out that the Revenue Management of lowcost airlines is based merely on the prices of the flight tickets. The objective is the optimization of the ticket prices over the whole sales period. This is achieved by price adaptations over time in order to influence the demand. A price too low at the beginning of the selling period fills up the aircraft too fast, whereas a too high price means the airline won't sell all available seats. In Figure 3 the principal idea of the Revenue Management of low-cost airlines is illustrated.

Figure 3 - Revenue management of low-cost carriers

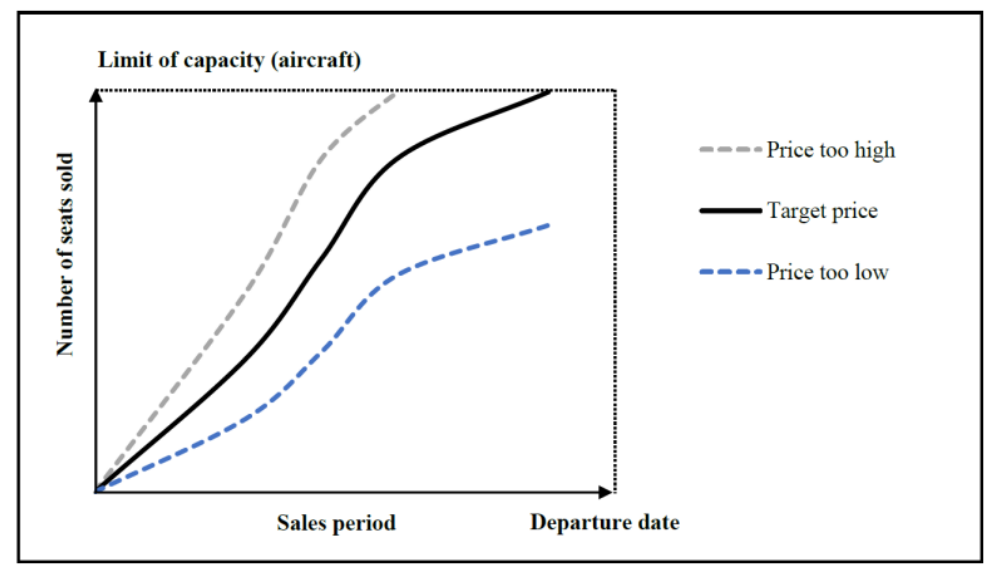

Source: adapted from Cento (2009). 
The intention of the airline is to follow a determined sales pattern, which is indicated by the solid black line in Figure 3. By doing so, the aircraft fills up just before the departure date and profits are maximized. The blue dashed line implies that the airfare for the flight was, in general, too high over time, leaving many seats unsold. In contrast, a sales pattern like that represented by the grey dashed line means that the ticket price was too low and the aircraft fills up too fast. This means that already quite long before the departure date all seats are sold and no tickets are left for passengers having the intention to purchase a flight shortly before departure, which involves a very high willingness to pay.

From a passenger's perspective, the Revenue Management of low-cost airlines is straightforward and very easy to understand. Furthermore, passengers consider it logical that airfares are cheaper when bought a long time in advance and very expensive when purchased shortly before departure, as Friesen and Reinecke (2007) remark. This avoids perceived injustice and dissatisfaction of customers who paid more for their flight than others.

Overbooking is not very common among low-cost airlines, as Michaels and Fletcher (2009) stress. For example, the Irish lowcost airline Ryanair does not make use of overbooking at all (Ryanair, 2018). The reason why overbooking is not very popular among low-cost airlines is the fact that if there is not enough capacity for all passengers on a flight, this could cause serious trouble for customers who were denied boarding, since there is not always a high frequency of their flights being offered. This not only results in high dissatisfaction of the passenger who had to change their flight, but also in high costs for the airline in the form of compensation (Koenigsberg, Muller and Vilcassim, 2008; Marcus \& Anderson, 2008).

\section{Recent developments in pricing}

Until not so long ago, network carriers and low-cost airlines followed their marketing strategies in a very strict way. However, the continuous market entry of new airlines, along with other problems such as declining growth rates of demand for air travel, has led to decreasing revenues for airline companies. As a consequence, airlines have been forced to optimize their business strategies, which also includes their pricing policy (Cento, 2009; Maurer, 2006).

Concerning network carriers, several developments can be noted recently:

One important strategic adaptation which can be observed among traditional airlines recently is the unbundling of the additional services. Dennis (2007) and O'Connell (2011) explain that the main reason why network carriers started to offer additional services separately was to be able to reduce ticket prices and better compete against low-cost airlines. However, as O'Connell and Warnock-Smith (2013) remind us, there are limits for traditional airlines in this context, since passengers were used to having these services included in the airfare. The study of Tuzovic, Simpson, Kuppelwieser \& Finsterwalder (2014) shows that especially the extra charges for luggage cause high dissatisfaction of travellers of traditional airlines.

Another trend can be detected with respect to the offered travel classes. Many network carriers started to introduce the new so-called Premium Economy class on their long-haul flights. This new travel class offers more comfort in the form of legroom compared to the classic Economy class, as well as higher quality in the services provided during the flight, e.g. catering during the flight. The target group of this new travel class are wealthy tourists, who accept a price premium for somewhat more luxury, yet are not willing to pay the much higher prices of the business class (Conrady et al., 2013). Although the Premium Economy class helps to better meet the needs of the individual customer groups, its implementation is also associated with risks. Since the business class is the most profitable travel class (Hanlon, 2007), airlines have to avoid having too many business travellers migrate to this new Premium Economy class. Furthermore, an additional travel class also necessitates a more complex Revenue Management.

In the same way, also low-cost airlines have made many strategy modifications with regard to pricing in the recent past:

One significant development in pricing of low-cost airlines is the reduction of the immense charges for additional services, which was necessary due to the increasing frustration among passengers. Opinion polls show that, especially, the extraordinarily high baggage fees resulted in high dissatisfaction of clients (Hegenauer, 2018). As Trentmann (2018) states, these high fees caused the image of low-cost airlines to decline rapidly over the last years and passengers started to turn away from these airlines. Consequently, although being a primary source of revenues, lowering these charges and also penalty fees, e.g. when exceeding the baggage allowance, was inevitable.

Since growth rates have been declining recently, several lowcost airlines have started to actively attract more business customers. To adapt to the needs of this customer group, beside increasing service quality, low-cost airlines also implemented new tariffs, which are flexible and permit flight changes and annulations (Slodczyk, 2012). These new tariffs, however, could result in fundamental changes in the Revenue Management system of low-cost airlines. As discussed earlier, low-cost airlines usually do not make use of overbooking. However, due to these new flexible tickets, especially on routes with a high percentage of business travellers, this could lead to many free seats, caused by many no-shows. Consequently, lowcost airlines could be forced to rethink their strict denial of overbooking and allow it, at least, on certain flights. Besides, also the efforts of increasing the quality of services to better meet the needs of time-sensitive business travellers, e.g. serving big and easy accessible airports instead of small rural airports, could influence the pricing of these airlines. Since 
these measures imply higher costs, airlines could be forced to increase the general price level of their airfares.

As the analysis shows, both types of airline have made some considerable strategic changes recently. Whereas some seem absolutely reasonable, e.g. the fee reduction of low-cost airlines, other measures involve uncertainties and their long-term success is yet to be confirmed. Furthermore, as the discussion revealed, certain strategic decisions cannot be considered independently since they influence other instruments, more specifically, the Revenue Management of the airline.

\section{Conclusions}

The implementation of an appropriate pricing policy in accordance, on the one hand, with the business model and, on the other hand, with the characteristics of the targeted customer segments, is fundamental for the success of any airline. However, this is a difficult task, since pricing in the airline business is multifaceted and many different aspects have to be considered.

In the present paper we analysed the pricing strategies of the two most important types of airline in the market: traditional carriers and low-cost airlines. The study discovered many differences, resulting from the fact that these types are characterized by very different fundamental business models and, correspondingly, also target groups. Whereas network carriers offer a differentiated service to their target groups, which are relatively price-sensitive vacationers and also time-sensitive but priceinsensitive business travellers, low-cost airlines mainly target extremely price-sensitive leisure travellers, offering air transportation at the lowest prices. The analysis showed that not only the general price level differs substantially between network carriers and low-cost airlines, but also the tariff systems, the manner of offering additional services, the geographical pricing strategies, as well as the implementation of other measures, such as loyalty programmes.

One instrument of significant importance in air transportation to increase profits is dynamic pricing in the form of Revenue Management. The objective is to maximize capacity usage and, at the same time, make use of the higher willingness to pay of customers, firstly, when traveling in peak seasons and, secondly, when purchasing the flight shortly before departure. Although the fundamental idea is the same, due to the many differences regarding the overall business strategy, the implemented Revenue Management systems differ significantly between network carriers and low-cost airlines. The Revenue Management of network carriers is focused on the management of capacity and is carried out in the way that in individual price intervals during the selling period certain contingents of distinct tickets prices are offered. These contingents of each ticket price are determined and adapted over time according to the current capacity usage of the aircraft. The Revenue Management of network carriers is characterized by high complexity. Since different travel classes are provided, each of them has to be handled individually.
Besides, the many connecting flights and the participation in alliances complicate the Revenue Management of network carriers as well. In contrast, low-cost carriers established a fairly easy Revenue Management system. The ticket price is raised continuously during the sales period and adapted when the forecast demand does not meet the real demand. Also the limitation to only one travel class, the offer of merely direct flights, the avoidance of code-share agreements as well as the abstinence from overbooking are aspects which reduce the complexity of the Revenue Management of these airlines.

In general, also nowadays, network carriers as well as low-cost airlines still follow their characteristic pricing strategies. However, the market became very dynamic lately and both airline types adapted their pricing policies, at least to a certain extent. More specifically, network carriers took over some promising measures from the business model of low-cost carriers, whereas the latter implemented several corrective actions in order to better meet customer needs. With regard to network carriers, the change with most relevance is the unbundling of services and offering them separately to their customers. Yet, this is also the most controversial strategy change, since passengers expect certain services included when purchasing flights from these airlines. Therefore, Wittmer and Rowley (2014) recommend that the additional services offered separately should be limited to the ones which were not always included free of charge in the past, e.g. access to VIP lounges. With reference to low-cost airlines, due to increasing dissatisfaction of their customers, this airline type had to reduce the fees for their additional services. This, however, has had a great impact on their overall business model, since the ancillary revenues generated from these charges are crucial for the profitability of low-cost carriers. As a consequence, these airlines could be forced to raise their airfares in the future, which would affect their competitive advantage in the market.

The implementation of a proper pricing policy is a challenging task for airlines. Not only do many aspects have to be considered, but also certain tools, such as Revenue Management, can wind up being very complex. It is important that any kind of pricing adaptations be considered very carefully, because of possible unfavourable side-effects. As Friesen and Reinecke (2007) emphasize, this is especially the case with regard to tariffs and conditions, since many of them serve to separate different customer groups, e.g. a minimum stay restriction in the destination in order to separate vacationers from business travellers. Besides, neither can the needs and expectations of the target groups be neglected when considering strategic adaptations. For example, the study of Balcombe, Fraser and Harris (2009) shows that customers of network carriers search for high-quality air transportation with certain services included and are also willing to pay for it. Consequently, there is no need for these airlines to concentrate on lowering their ticket prices, but rather they should focus on offering their target groups an appropriate service of air transportation, which best meets their needs and expectations. In contrast, low-cost carriers, which are 
currently trying to increase their attractiveness for business travellers by focusing on service quality, should not lose sight of their main target group. Since these are very price-sensitive passengers who are only looking for cheap air transportation, increased service quality accompanied by higher airfares are not in the interest of this customer group.

\section{Acknowledgements}

This paper is financed by National Funds provided by FCTFoundation for Science and Technology through project UID/SOC/04020/2013.

\section{References}

Amaruchkul, K. \& Sae-Lim, P. (2011). Airline overbooking models with misspecification. Journal of Air Transport Management, 17(2), 143-147. Baker, D. M. A. (2013). Service quality and customer satisfaction in the airline industry: A comparison between legacy airlines and low-cost airlines. American Journal of Tourism Research, 2(1), 67-77.

Balcombe, K., Fraser, I. \& Harris, L. (2009). Consumer willingness to pay for in-flight service and comfort levels: A choice experiment. Journal of Air Transport Management, 15(5), 221-226.

Böhler, H. \& Scigliano, D. (2005). Marketing-Management. Stuttgart: Kohlhammer.

Cento, A. (2009). The airline industry: Challenges of the 21st Century. Berlin: Physica (Springer).

Çetiner, D. (2013). Fair revenue sharing mechanisms for strategic passenger airline alliances. Berlin: Springer.

Chin, A. T. H. (2002). Impact of frequent flyer programs on the demand for air travel. Journal of Air Transportation, 7(2), 53-86.

Clark, P. (2007). Buying the big jets: Fleet planning for airlines, 2nd ed. Farnham: Ashgate Publishing Ltd.

Conrady, R., Fichert, F. \& Sterzenbach R. (2013). Luftverkehr: Betriebswirtschaftliches Lehr- und Handbuch, 5th ed. Munich: Oldenbourg Verlag.

Cross, R. G. (1995). An introduction to revenue management. In Jenkins D. (ed.) (1995). The handbook of airline economics. New York: McGrawHill, 443-458.

Cross, R. G. (1997). Revenue management: Hard-core tactics for market domination. New York: Broadway Books.

De Boer, E. R. \& Gudmundsson, S. V. (2012). 30 years of frequent flyer programs. Journal of Air Transport Management, 24, 18-24.

Dennis, N. (2007). End of the free lunch? The responses of traditional European airlines to the low-cost carrier threat. Journal of Air Transport Management, 13(5), 311-321.

Dettmer, H., Hausmann, T. \& Schulz, J. M. (2008). TourismusManagement. Munich: Oldenbourg Verlag.

Doganis, R. (2010). Flying off course: Airline economics and marketing, 4th ed. London: Routledge.

Dolnicar, S., Grabler. K., Grün, B. \& Kulnig, A. (2011). Key drivers of airline loyalty. Tourism Management, 32(5), 1020-1026.

Domanico, F. (2007). The European airline industry: law and economics of low cost carriers. European Journal of Law and Economics, 23(3), 199-221.

Donaghy, K., McMahon-Beattie, U. \& McDowell, D. (1997). Yield management practices. In Yeoman I. \& Ingold I. (eds.). Yield management - Strategies for the service industries. London: Cassell, 183-201.

Edgett, S. \& Parkinson, S. (1993). Marketing for service industries - A review. The Service Industries Journal, 13(3), 19-39.

EUROPA (2018). Pricing and payments. URL: https://europa.eu/youreurope/citizens/consumers/shopping/pricingpayments/index_en.htm (accessed on 05.05.2018).
Frank, M., Friedemann, M., Mederer, M. \& Schroeder, A. (2006). Airline revenue management: A simulation of dynamic capacity management. Journal of Revenue \& Pricing Management, 5(1), 62-71.

Friesen, M. \& Reinecke, S. (2007). Wahrgenommene Preisfairness bei Revenue Management im Luftverkehr. Thexis: Fachzeitschrift für Marketing des Instituts für Marketing und Handel an der Universität St. Gallen, 24(4), 34-39.

Gilbert, D. \& Wong, R. K. C. (2003). Passenger expectations and airline services: A Hong Kong based study. Tourism Management, 24(5), 519532.

Gillen, D. \& Morrison, W. G. (2003). Bundling, integration and the delivered price of air travel: Are low cost carriers full service competitors? Journal of Air Transport Management, 9(1), 15-23.

Graf, M. \& Kimms, A. (2013). Transfer price optimization for optionbased airline alliance revenue management. International Journal of Production Economics, 145(1), 281-293.

Gursoy, D. \& Gafcar, E. (2003). International leisure tourists' involvement profile. Annals of Tourism Research, 30(4), 906-926.

Hanlon, P. (2007). Global Airlines: Competition in a Transnational Industry, 3rd ed. Oxford: Elsevier Butterworth-Heinemann.

Hegenauer, M. (2018). Milliardengeschäft: Die ärgerlichsten Zusatzgebühren beim Fliegen. URL: https://www.welt.de/reise/article127298243/Die-aergerlichstenZusatzgebuehren-beim-Fliegen.html (Accessed on 12.03.2018).

Heidig, W. \& Tomczak, T. (2014). Revenue Management aus Kundensicht. In Tomczak T. \& Heidig W. (eds.) (2014). Revenue Management aus der Kundenperspektive: Grundlagen, Problemfelder und Lösungsstrategien. Wiesbaden: Springer Gabler Verlag, 1-18.

Hess, S., Adler, T. \& Polak, J. W. (2007). Modelling airport and airline choice behaviour with the use of stated preference survey data. Transportation Research: Part E, 43(3), 221-233.

Klein, R. (2001). Revenue Management: Quantitative Methoden zur Erlösmaximierung in der Dienstleistungsproduktion. Betriebswirtschaftliche Forschung und Praxis, 53, 245-259.

Klein, R. \& Steinhardt, C. (2008). Revenue Management: Grundlagen und Mathematische Methoden. Berlin: Springer.

Koenigsberg, O., Muller, E. \& Vilcassim, N. J. (2008). Easyjet ${ }^{\circledR}$ pricing strategy: Should low-fare airlines offer last-minute deals? Quantitative Marketing \& Economics, 6(3), 279-297.

Lawton, T. C. (2002). Cleared for take-off: Structure and strategy in the low fare airline business. Farnham: Ashgate Publishing Ltd.

Lindenmeier, J. \& Tscheulin, D. K. (2008). The effects of inventory control and denied boarding on customer satisfaction: The case of capacity-based airline revenue management. Tourism Management, 29(1), 32-43.

Luo, L. \& Peng, J. (2007). Dynamic pricing model for airline revenue management under competition. Systems Engineering - Theory \& Practice, 27(11), 15-25.

Malaval, P., Bénaroya, C. \& Aflalo J. (2014). Aerospace marketing management: $A$ handbook for the entire value chain. Cham: Springer.

Malighetti, P., Paleari, S. \& Redondi, R. (2009). Pricing strategies of lowcost airlines: The Ryanair case study. Journal of Air Transport Management, 15(4), 195-203.

Marcus, B. \& Anderson, C. K. (2008). Revenue management for low-cost providers. European Journal of Operational Research, 188(1), 258-272.

Maurer, P. (2006). Luftverkehrsmanagement: Basiswissen, 4th ed. Munich: Oldenbourg Verlag.

Mensen, H. (2013). Handbuch der Luftfahrt, 2nd ed. Wiesbaden: Springer Vieweg.

Michaels, L. \& Fletcher, S. (2009). Competing in an LCC world. Journal of Revenue \& Pricing Management, 8(5), 410-423.

Michel, S. \& Zellweger, C. (2014). Pricing bei Dienstleistungen und Yield Management. In Tomczak T. \& Heidig W. (eds.) (2014). Revenue 
Management aus der Kundenperspektive: Grundlagen, Problemfelder und Lösungsstrategien. Wiesbaden: Springer Gabler, 43-62.

Nako, S. M. (1992). Frequent flyer programs and business travellers: An empirical investigation. Logistics and Transportation Review, 28(4), 395-414.

Narangajavana, Y., Garrigos-Simon, F. J., Garcia, J. S. \& Forgas-Coll, S. (2014). Prices, prices and prices: A study in the airline sector. Tourism Management, 41, 28-42.

O'Connell, J. F. (2011). Ancillary revenues: The new trend in strategic airline marketing. In O'Connell J. F. \& Williams G. (eds.) (2011). Air Transport in the 21st Century: Key strategic developments. Farnham: Ashgate Publishing Ltd., 145-170.

O'Connell, J. F. \& Warnock-Smith, D. (2013). An investigation into traveller preferences and acceptance levels of airline ancillary revenues. Journal of Air Transport Management, 33, 12-21.

O'Connell, J. F. \& Williams, G. (2005). Passengers' perceptions of low cost airlines and full service carriers: A case study involving Ryanair, Aer Lingus, Air Asia and Malaysia Airlines. Journal of Air Transport Management, 11(4), 259-272.

Oliveira, A. V. M. (2008). An empirical model of low-cost carrier entry. Transportation Research Part A: Policy and Practice, 42(4), 673-695.

Perlitz, M. (2004). Internationales Management, 5th ed. Stuttgart: Lucius \& Lucius.

Pfeifer, P. E. (1989). The airline discount fare allocation problem. Decision Sciences, 20(1), 149-157.

Phillips, R. L. (2005). Pricing and revenue optimization. Palo Alto: Stanford Business Books.

Pompl, W. (2007). Luftverkehr - Eine ökonomische und politische Einführung, 5th ed. Berlin: Springer.

Porter, M. E. (1985). Competitive advantage: Creating and sustaining superior performance. New York: The Free Press.

Ruperti, F. (2012). Marketing von Low-Cost-Airlines. In Zerres M. \& Zerres C. (eds.) (2012). Hamburger Schriften zur Marketingforschung, vol. 81. Munich: Rainer Hampp.

Ryanair (2018). Passenger Charter. URL: https://corporate.ryanair.com/about-us/passenger-charter (Accessed on 07.03.2018).

Schulz, A. (2009). Verkehrsträger im Tourismus: Luftverkehr, Bahnverkehr, Straßenverkehr, Schiffsverkehr. Munich: Oldenbourg Verlag.

Shaw, S. (2011). Airline marketing and management, 7th ed. Farnham: Ashgate Publishing Ltd.

Slodczyk, K. (2012). Inside Easyjet: Bei Geschäftskunden gut gelandet. Handelsblatt, January, 27, 2012, p. 12.

Sorensen, J. (2018). 2016 Top 10 airline ancillary revenue rankings. URL: http://www.ideaworkscompany.com/wp-

content/uploads/2017/07/2016-Top-10-Airline-Ancillary-RevenueRankings.pdf (Accessed on 23.03.2018).

Stuhlmann, S. (2000). Kapazitätsgestaltung in Dienstleistungsunternehmen - Eine Analyse aus der Sicht des externen Faktors. Wiesbaden: DUV.

Talluri, K. T. \& Van Ryzin, G. J. (2004). The Theory and Practice of Revenue Management. New York: Springer.

Trentmann, N. (2018). Ryanair verlangt für Übergepäck nur noch die Hälfte.

URL: https://www.welt.de/wirtschaft/article122818041/Ryanair-verlangtfuer-Uebergepaeck-nur-noch-die-Haelfte.html, (Accessed on 02.03.2018).

Tretheway, M. W. (2004). Distortions of airline revenues: Why the network airline business model is broken. Journal of Air Transport Management, 10(1), 3-14.

Tuzovic, S., Simpson, M. C., Kuppelwieser, V. G. \& Finsterwalder, J. (2014). From 'free' to fee: Acceptability of airline ancillary fees and the effects on customer behavior. Journal of Retailing and Consumer Services, 21(2), 98-107.

Vasigh, B., Fleming, K. \& Tacker, T. (2013). Introduction to Air Transport Economics: From Theory to Applications, 2nd ed. Farnham: Ashgate Publishing Ltd.

Wagner, O. (2005). Kundenbindung: Miles \& More - Kundenbindung in der Luft. In Künzel H. (ed.) (2005). Handbuch Kundenzufriedenheit: Strategie und Umsetzung in der Praxis. Berlin et al.: Springer, 135-154.

Walczak, D., Boyd, E. A. \& Cramer, R. (2012). Revenue Management. In Barnhart C. \& Smith B. (eds.) (2012). Quantitative problem solving methods in airline industry: A modelling methodology handbook. New York: Springer, 101-162.

Wang, X. \& Meng, Q. (2008). Continuous-time dynamic network yield management with demand driven dispatch in the airline industry. Transportation Research: Part E, 44(6), 1052-1073.

Weatherford, L. R. (1997). A tutorial on optimization in the context of perishable asset revenue management problems for the airline industry. In: Yu G. (ed.) (1997). Operations research in the airline industry. Boston: Kluwer, 68-100.

Weatherford, L. R. (2009). Survey results from airlines that use revenue management software systems. Journal of Revenue \& Pricing Management, 8(4), 323-329.

Wehner, C., López-Bonilla, J. M. \& López-Bonilla, L. M. (2017). Service quality in the passenger air transport industry. In Collins A. (ed.) (2017). Service quality (SQ): Perspectives, management and improvement strategies. New York: Nova Science Publishers Inc., 59-80.

Wirtz, J. \& Heidig, W. (2014). Wahrgenommene Preisfairness und Ansätze zur Konfliktlösung im Revenue Management. In Tomczak T. \& Heidig W. (eds.) (2014). Revenue Management aus der Kundenperspektive: Grundlagen, Problemfelder und Lösungsstrategien. Wiesbaden: Springer Gabler, 83-104.

Wittmer, A. \& Rowley, E. (2014). Customer value of purchasable supplementary services: The case of a European full network carrier's economy class. Journal of Air Transport Management, 34, 17-23.

Received: 18.12.2017

Revisions required: 12.03 .2018

Accepted: 26.06 .2018

\section{Guest Editors:}

- J. A. Campos-Soria

- J. Diéguez-Soto

- M. A. Fernández-Gámez 